\title{
PRÓBA ARGUMENTACJI ZA ONTYCZNĄ PROSTOTĄ PRZYRODY
}

Poszukiwanie elementów zarówno ontycznej prostoty przyrody, jaï i poznawczej prostoty ujęć teoretycznych posiada dawne tradycje w myśli filozoficznej. Wyrazem tych poszukiwań były w przeszłości rozważania Pitagorejczyków o harmonii kosmosu, scholastyczna zasada simplex sigillum veri czy Keplerowskie adagium Natura simplicitatem amat. Mimo tych tradycji, merytoryczne rozważania nad tym zagadnieniem pozostają jeszcze ciągle $w$ stadium klasyfikacyjno-terminologicznych rozróżnień, natomiast propozycje oceny stopnia prostoty są ustawicznie modyfikowane. Przełom lat czterdziestych i pięćdziesiątych naszego stulecia był okresem odejścia od pewnych uprzedzeń popularnych wśród pozytywizujących filozofów nauki. Autorzy ai w megatywnej ocenie kryterium prostoty zwracali uwagę, iż jest ono niesprecyzowane, niejasne, uwarunkowane subiektywnie, niewyraźne i niemożliwe do opracowań ilościowych ${ }^{1}$. W następstwie podobnych ocen wielu autorów uważało próby wykorzystania kryterium prostoty $\mathrm{w}$ metodologii za beznadziejne ${ }^{2}$, a uwagi o estetyczno-formalnych walorach teorii przyrodniczych za subiektywny, zbędny komentarz ${ }^{3}$.

Po trzydziestu latach dokładniejszych analiz zagadnienia nie podziela się już wielu wcześniejszych obiekcji i zwraca uwagę, że trudności z definiowaniem, określeniem kryteriów, uwzględnieniem wielu dodatkowych wskaźników występują nie tylko przy ocenie prostoty rozwiązań, ale także przy określaniu temperatury czy rozmiarów obiektów fizycznych 4 . Samo odejście od uprzedzeń poprzedniego okresu nie doprowadziło jed-

1 Por. N. Goodman, The Test of Simplicity, w: Problems and Projects, New York 1972, 282.

2 Tamże, 281.

3 Por. S.F. Barker, On Simplicity in Empirical Hypotheses, „Phil. of Sc.”, 28 (1961) 162. „Many writers seeing the grave difficulties seem to lie in the way of any precise, general definition of simplicity have concluded that the notion is itself ultimately only an aesthetic one, a matter of taste". S. 170.

4 Goodman, 282. 
nak do rozwiązania nawet podstawowych kwestii dotyczących prostoty teorii przyrodniczych. Po latach wielokierunkowych badań problemu prostoty istnieje wiele publikacji dotyczących tej tematyki, ale nie istnieje zgoda odnośnie do wyznaczników prostoty i decyzje podejmowane przy ocenie konkretnych rozwiązań różnią się krańcowo. W tym kontekście uzasadnione jest podjęcie własnej próby argumentacji za najbardziej podstawowym z wszystkich typów prostoty, mianowicie za ontyczną prostotą przyrody.

\section{USTALENIA TERMINOLOGICZNE}

W precyzujących klasyfikacjach wyróżnia się obecnie ponad 20 typów prostoty. M. in. bada się prostotę absolutną i prostotę względną, prostotę założeń i prostotę następstw logicznych, prostotę ontyczną i gnozeologiczną (poznawczą), pozalogiczną i opisową, obiektywną i subiektywną, strukturalną, psychologiczną, logiczną, epistemologiczną, poznawczą, pragmatyczną, techniczną, algorytmiczną, syntaktyczną, semantyczną, matematyczną, formalną, indukcyjną, lingwistyczną etc. Przy niektórych wymienionych typach wymienia się w dalszych, bardziej szczegółowych dyferencjacjach różnorodne podtypy (np. semantyczna prostota założeń i semantyczna prostota terminów). W odmiennych klasyfikacjach niejednokrotnie zróżnicowane terminy denotują ten sam typ prostoty. $\mathrm{Z}$ kolei $\mathrm{w}$ innych ujęciach dla oznaczania zróżnicowanych typów wprowadzane są identyczne terminy. Istniejący chaos terminologiczny prowadzi do sytuacji, w której czynnością psychologicznie skomplikowaną staje się samo zrozumienie definicji prostoty ${ }^{5}$. W takim kontekście zrozumiałe jest np. stanowisko Ireny Szumilewicz, która nie podejmując szczegółowych analiz różnych typów prostoty, poprzestaje na ogólnym stwierdzeniu: „Występujące w literaturze... próby sprecyzowania terminu „prostota”, ewentualnie relacji „prostszy miż” są niezadowalające. Dlatego też nie będziemy ich omawiać" ${ }^{6}$.

W bardziej maksymalistycznych ujęciach podejmowane są próby określenia bezwzględnej lub względnej prostoty poszczególnych rozwiązań. W drugim $z$ sygnalizowanych przypadków bada się, które $\mathrm{z}$ określonej klasy konkurencyjnych rozwiązań jest względnie (tzn. $\mathrm{w}$ odniesieniu do badanej klasy) najprostsze. W tym celu analizuje się własności terminów podstawowych występujących w rozwiązaniach -

5 R. Rudner stwierdza np., że na podstawie precyzacji terminologicznych przedstawionych przez M. Bunge'a nie potrafii on zrozumieć, na czym polega prostota semantyczna, epistemologiczna lub metafizyczna definiowana przez M. Bunge'a, An Introduction to Simplicity, „Phil. of Sc.”, 28 (1961) 118.

'I. Szumilewicz, Prostota a prawda, "Gdańskie Zesz. Hum.", 2 (1966) 82. 
ich zwrotność, tranzytywność, symetryczność, zupełność 7 itp. Niektóre $\mathrm{z}$ proponowanych zasad oceny rażą swą arbitralnością czy prowadzą do wniosków trudnych do pogodzenia z powszechnymi intuicjami. Dla przykładu - w Kemeny'ego ${ }^{*}$ koncepcji prostoty 4-miejscowy predykat dotyczący zbioru składającego się z zaledwie 20 elementów ma stopień złożoności 160 000. Analogicznie w koncepcji Goodmana ${ }^{9}$ zakłada się, iż stopień komplikacji klasy an - miejscowych predykatów całkowicie niezwrotnych, zupełnych i symetrycznych jest równy jedności, podczas gdy stopień komplikacji klasy $\mathrm{n}$ - miejscowych predykatów całkowicie niezwrotnych wynosi $2 \mathrm{n}-1$. $\mathrm{Z}$ innych powodów można polemizować $\mathrm{z}$ propozycją, w której zdaniom $\mathrm{f}(\mathrm{x})=1 / 4$ i $\mathrm{f}(\mathrm{x})=0,25$ przypisuje się odmienne stopnie prostoty ${ }^{10}$.

Pomijając arbitralny charakter podobnych propozycji zauważyć trzeba, iż teoretycznie mogłyby one być przydatne przy ocenie stopnia prostoty pojedynczych zdań, których stopień komplikacji struktury uzależniony jest w dużej mierze od wprowadzonych terminów podstawowych. Znacznie bardziej trudnym zadaniem jest ocena prostoty nie pojedynczych zdań, lecz całych teorii. W przypadkach takich mieistotna jest liczba miejsc predykatów czy ich zwrotność, gdyż decydujący charakter mają wówczas semantyczne i formalne walory ocenianych teorii.

Przy ocenie semantycznej prostoty teorii uwzględniana jest zarówno ekonomia terminów występujących w podstawowych założeniach, jak $i$ ich treść; natomiast $w$ analizach prostoty formalnej abstrahuje się od porównywania treści analogicznych terminów i zwraca uwagę jedynie na formalne walory opisu. Zarówno prostota semantyczna, jak i formalna stanowią podtypy prostoty gnozeologicznej nazywanej także prostotą poznawczą. W prostocie tego typu ocenia się stopień złożoności twịerdzeń będących wynikiem różnorodnych procesów poznawczych. Sam proces poznania ma jednak strukturę na tyle złożoną, iż wzrost prostoty określonego typu pociąga za sobą nierzadko wzrost komplikacji innych typów prostoty. I tak na przykład wzrost stopnia prostoty formalnej założeń określonej teorii prowadzi do wzrostu komplikacji konsekwencji logicznych tej teorii. Za klasyczny przykład tego typu sytuacji można uznać teorię stanu stałego. Konstruowane na bazie jej założeń modele wszechświata stacjonarnego są w pewnych aspektach gnozeologicznie prostsze od rozwiązań konkurencyjnych. W modelach tych gęstość

7 Przez zupełność predykatów rozumie Goodman tę ich własność, dzięki której określony predykat występujący między terminami $x$ i $y$ oraz terminami w i z może być również użyty w sposób semantycznie sensowny i poprawny między terminami $\mathrm{x}$ i $\mathrm{z}$.

8 J.G. Kemeny, The Use of Simplicity in Induction, „Phil. Rev.”, 57 (1953) 403; R. Ackermann, Inductive Simplicity, „Phil. of Sc.”, 28 (1961) 154

${ }^{9} \mathrm{Dz}$. cyt., 293.

10 Zob. J. Kemeny, art. cyt. 
materii nie ulega zmianie w czasie, wyeliminowane zostają trudności z wyjaśnianiem genezy stanu osobliwego etc. Równocześnie jednak modele wszechświata stacjonarnego implikują odrzucenie fundamentalnej zasady fizyki - zasady zachowania energii, i $z$ tej racji uważane są przez wielu autorów za bardziej skomplikowane od modeli ewolucyjnych.

Podobny dualizm ocen występuje przy jednorodnych i izotropowych modelach kosmologicznych. Ze wzrostem liczby założeń wprowadzanych w poszczególnych modelach wzrasta ich prostota pragmatyczna i algorytmiczna. Wzrostowi temu towarzyszy jednak obniżenie semantycznej prostoty ùjęć.

Przy ocenie heurystycznych funkcji teorii naukowych uwzględniać trzeba fakt, iż prostota algorytmiczna, psychologiczna, pragmatyczna czy techniczna może być co najwyżej drugorzędnym wskaźnikiem wartości teorii. Prostota algorytmiczna, odwrotnie proporcjonalna do liczby obliczeń wymaganych do rozwiązania równań wchodzących w skład danej teorii, prowadziłaby w praktyce badawczej do preferowania równań nie wymagających dużej ilości obliczeń. Trudności obliczeniowe mogą być jednak wynikiem niedoskonałości aparatu matematycznego $\mathrm{w}$ danym stadium rozwoju teorii, podobnie jak trudności obserwacyjne mogą być następstwem relatywnie hiskiego poziomu aparatury technicznej. Z udoskonaleniem aparatu trudności te mogą zniknąć, stąd też ten typ prostoty nie może spełniać podstawowej roli w analizach filozofów nauki. Podobnie jest z prostotą psychologiczną, której wskaźnikiem są m. in. opory psychiczne towarzyszące recepcji nowej teorii. Wskaźnik ten może być interesujący dla historyków nauki, którzy np. badają reakcje społeczne- na radykalnie nowe założenia fizyki. Nie może on być jednak heurystyką dla kosmologów, gdyż konsekwencją jego przyjęcia musiałoby być $\mathrm{m}$. in. preferowanie geocentryzmu, który w pewnych okresach budził znacznie mniejsze opory psychiczne niż heliocentryzm.

Poszukiwanie wskaźników prostoty teorii naukowych można uzasadniać przez samą ekonomię badań. Zazwyczaj jednak u podstaw tych poszukiwań znajduje się przekonanie, że nie tylko teorie naukowe powinny być proste, ale także, iż przyroda w swych strukturach preferuje prostotę. Owa prostota obiektywnie istniejących struktur przyrody, w dalszym ciągu artykułu nazywana prostotą ontyczną, może stanowić głębsze uzasadnienie dla metodologicznych poszukiwań prostoty gnozeologicznej. Samo uzasadnienie tezy o ontycznej prostocie struktur przyrody wydaje się jednak trudniejsze i bardziej skomplikowane niż uzasadnienie tezy o preferowaniu określonego typu prostoty gnozeologicznej jako kryterium heurystycznego. W miniejszym artykule zawarta 
jest właśnie nowa próba argumentacji za ontyczną prostotą przyrody nawiązująca do jej podatności na idealizację oraz do antyprzypadkowego charakteru procesów fizycznych.

\section{ZAGADNIENIE ONTYCZNEJ PROSTOTY PRZYRODY}

W historii nauki przekonanie o heurystycznej wartości kryterium prostoty znalazło majpełniejszy wyraz, w zasadzie tzw. brzytwy Ockhama. Sformułowana w XIV wieku zasada była stosowana w praktyce badawczej przez wielu przyrodników następnych stuleci. Podzielając pogląd, iż entia non sunt multiplicanda praeter necessitatem M. Kopernik podkreślał, iż teoria heliocentryczna jest prostsza od geocentrycznej, Galileusz wykazywał, że należy odrzucić fizykę Arystotelesa jako zbyt skomplikowaną, zaś Newton orzekał, iż „Natura cieszy się prostotą i nie pyszni się tym, co jest zbędne".

Uznanie kryterium prostoty za przydatne metodologicznie nie' stanowi jednak odpowiedzi na pytanie, czy przyroda jest obiektywnie, miezależnie od opisujących teorii, prosta w swych strukturach ontycznych. Wśród argumentów za ontyczną prostotą Natury najczęściej wymieniany jest argument historiograficzny odwołujący się do faktu, iż w procesie rozwoju nauki najbardziej zbliżone do prawdy olkazywały się rozwiązania inspirowane przekonaniem o ontycznej prostocie świata ${ }^{11}$. Przy ocenie tego argumentu należy dostrzec, iż podjęcie decyzji, która z konkurencyjnych teorii suponuje maksymalną prostotę ontyczną Natury, nie zawsze było możliwe na gruncie paradygmatu; w którym zachodził konflikt między teoriami. I tak np. teoria Kopernika była prostsza od teorii Ptolomeusza, jeśli uwzględniało się fakt, że liczba epicykli była w niej prawie pięciokrotnie mniejsza (17, a nie 83). Kiedy jednak brano pod uwagę różne rodzaje ruchów, trzeba było uznać rozwiązanie Ptolomeusza $\mathrm{z}$ jednym rodzajem ruchu za prostsze, gdyż w ujęciu Kopernika uwzględniane były trzy rodzaje ruchu (precesyjny, wokół Słońca i wokół osi). W tej sytuacji niełatwe było podjęcie jednoznacznej decyzji, które $\mathrm{z}$ proponowanych rozwiązań opisuje wszechświat ontycznie prostszy. Dopiero po odkryciach Keplera można było preferować koncepcję heliocentryczną, ale decyzje takie jeszcze i dziś są przedmiotem dyskusji i niektórzy z filozofów mauki nadal kwestionują tezę o większej prostocie rozwiązania Kopernika ${ }^{12}$.

Przekonanie o ontycznej prostocie świata pełniło funkcje heurystyczne $w$ analizach P. Fermata dotyczących rozchodzenia się światła czy w dociekaniach D. Bernoulliego nad symetrią w przyrodzie. U podstaw

11 Por. I. Szumilewicz, art. cyt., 94.

12 Zob. T. Kuhn, Przewrót kopernikański, Warszawa 1966, 262. 
owych badań leżało przekonanie, które Galileuszowski Sagredo wymieniał jako naczelne założenie ,uważane przez wszystkich filozofów za słuszne” - założenie, iż przyroda „nie komplikuje zjawisk bez potrzeby i posługuje się najłatwiejszymi oraz najprostszymi sposobami" ${ }^{13}$. Formułując w 1744 r. zasadę najmniejszego działania P. Maupertuis odwoływał się właśnie do prostoty Natury i pisał o „,ważnej zasadzie, według której Przyroda przy realizacji poszczególnych procesów kroczy zawsze najprostszymi drogami" ${ }^{14}$. W 90 lat później W. Hamilton w Inctuguracyjnym wykładzie $z$ astronomii argumentował podobnie $\mathrm{i}$ w uzasadnieniu ,zasady minimum" twierdził, że przy ocenie wartości teorii trzeba uwzględniać jako naczelne kryteria prostotę i piękno. W konsekwencji Hamilton oceniał pozytywnie Keplerowskie prawa ruchu i ujęcie Lagrange'a w mechanice, $\mathrm{z}$ tej racji, iż posiadały one większą prostotę i piękno niż rozwiązania konkurencyjne.

Nie poprzestając na metodologicznym ujęciu zasady prostoty G. Leibniz, przedstawiciele mechanicyzmu, empiriokrytycyzmu i scjentyzmu próbowali uzasadniać tezę o ontycznej prostocie świata wyprowadzając ją jako konsekwencję bardziej zasadniczych założeń ontologicznych, W ujęciu Leibniza zasada ta miała ostateczną rację w Bogu, który stwarzając najlepszy $\mathrm{z}$ możliwych światów złączył $\mathrm{w}$ nim maksymalne bogactwo zjawisk $\mathrm{z}$ maksymalną prostotą opisujących je praw. Pozytywna ocena zasady w mechanicyzmie czy kierunkach scjentyzujących warunkowana była redukcjonizmem ontologicznym L. Boltzmanna, H. L. Helmholtza czy $K$. Pearsona oraz metafizycznym przekonaniem, iż wszystkie zjawiska można wyjaśnić przez odwołanie się do pojęć mechaniki lub — ogólniej — fizyki.

Arbitralne próby filozoficznego wykazywania ontycznej prostoty świata przyczyniły się do tego, iż obecnie wielu fizyków nazywa postulat prostoty ontycznej ,najbardziej kłopotliwym, nieuchwytnym i trudnym" postulatem metafizycznym współczesnego przyrodoznawstwa ${ }^{15}$. Postulat ten przyjmowany jest powszechnie w praktyce badawczej, a jego walory heurystyczne podkreślali m. in. A. Einstein, M. Planck, C. F. v. Weizsäcker, W. Heisenberg, P. A. M. Dirac, L. de Broglie $i$ in. Nie zmienia to faktu, iż autorzy ci albo przyjmują zasadę prostoty jako metodologiczny artykuł wiary ${ }^{16}$, albo usiłują usprawiedliwić

13 G. Galilei, Dialog o dwu układach świata Kopernikowym $i$ Ptolomeuszowym, Warszawa 1962, 426.

14 Sogłasowanije razlicznych zakonow prirody kotoryje do sich por kazalis' niesowmiestimymi, w: Warjacjonnyje principy miechaniki, Moskwa 1959, 27.

15 H. Margenau, The Nature of Physical Reality, New York 1950.

16 Por. np. Margenau, dz. cyt., $97 \mathrm{n}$. ,It is a plain confession of faith on the part of those who seek in scientific knowledge". Por. też W. van Orman Quine, On Simple Theories of a Complex World, "Synthese”, 15 (1963) 103. „Belief in the simplicity of Nature, and hence in the uniformity of Nature, can 
swe stanowisko przez odwołanie do filozoficznych założeń neokantyz$\mathrm{mu}$ lub neoplatonizmu ${ }^{17}$. Od zarzutu inspiracji neoplatońskich są wprawdzie wolni autorzy pozytywizujący, ale argumenty przytaczane przez nich również nie mogą być uznane za uzasadnione.

Rozróżnienie między metodologiczną i heurystyczną funkcją zasady prostoty a jej obiektywną wartością zostało wyakcentowane w operacjonizmie P. W. Bridgmana ${ }^{18}$. Twórca operacjonizmu uznawał inspirującą, pozytywną rolę zasady prostoty i nazywał ją ,najważniejszym z założeń" dotyczących przyrody ${ }^{19}$. $\mathrm{Na}$ podstawie danych historiograíii stwierdzał on również, że cały proces rozwoju nauki można rozpatrywać jako historię sprowadzania tego, co bardziej skomplikowane do tego, co prostsze. Przeciwstawiając „metodologicznym artykułom wiary” własne zasady metodologiczne Bridgman orzekał z wyraźnym subiektywizmem, że ,nie odczuwa sympatii" 20 do redukcjonistycznych wyjaśnień czy prób poszukiwania koincydencji liczbowych w skali kosmicznej. Przekonaniom optymistów gnozeologicznych przyjmujących tezę o prostocie przyrody przeciwstawiał on dane dotyczące trudności $z$ interpretacją mechaniki kwantowej ${ }^{21}$.

Wskazywany przez Bridgmana fakt istnienia pseudorozwiązań inspirowanych przez zasadę prostoty nie przesądza niczego o wartości tej zasady, gdyż wiele twierdzeń i zasad przyrodoznawstwa uważanych obecnie za prawdziwe inspirowało $\mathrm{w}$ przeszłości warianty rozwiązań, które zostały zarzucone. Podobnie przy ocenie zarzutu o skomplikowanym obrazie 'świata ukazywanym przez mechanikę kwantową należy zauważyć korelację między oceną stopnia prostoty danej teorii a stadium rozwoju paradygmatu naukowego zawierającego ocenianą teorię. Z rozwojem nauk przyrodniczych ujęcia uważane początkowo za naruszające elegancję lub symetrię okazywały się bardziej proste w nowym paradygmacie, po wprowadzeniu nowych zasad i pojęć. Wcześniejsza komplikacja ujęcia była wynikiem podtrzymywania aparatu pojęciowego dawnego paradygmatu. Miało to miejsce np. w teorii Kopernika, gdzie przyjęcie tezy o kołowych orbitach planet prowadziło w konsekwencji do konieczności wprowadzania epicykli. Po stwierdzeniu eliptycznego charakteru orbit planet wzrósł automatycznie stopień prostoty ujęcia Kopernikowskiego. W przypadku tym wzrost prostoty konsekwencji teorii następował równocześnie ze zmniejszaniem się prag-

be partially accounted in obvious ways. One plausible factor is wishful thinking".

17 Zob. np. C. F. von Weizsäcker, Jedność przyrody, Warszawa 1978.

18 The Logic of Modern Physic, New York 1927, 200.

19 Tamże.

20 Tamże, 203.

21 Tamże, 205-207. 
matycznej prostoty falsyfikacji. O ile bowiem hipotezę o kołowych orbitach planet można sfalsyfikować na podstawie pomiarów 4 położeń planety, to do falsyfikacji hipotezy o orbitach eliptycznych trzeøa obserwacji sześciu odmiennych położeń.

Niewątpliwe jest, że rozwiązania kosmologiczne prezentowane przez J. A. Wheelera, P. A. M. Diraca, D. I. Błochincewa czy L. E. Gurewicza, rozwiązania, w których dopuszcza się możliwość zmian w czasie pewnych parametrów tradycyjnie uważanych za niezmienne lub możliwość skokowej zmiany praw przyrody, ukazują bardziej skomplikowane struktury ontyczne, niż czynią to ujęcia opozycyjne. Gdyby jednak uznawać za wskaźnik prostoty niezmienność pewnych prawidłowości lub stabilność związków, wtedy za ideał prostoty ontycznej musiałby zostać uznany niezmienny świat Parmenidesa. W historii rozwoju nauki można tymczasem wskazać liczne przypadki, w których odejście od początkowych idealizujących ujęć, w jakich w sposób sztuczny usiłowano bronić prostoty ontycznej, doprowadziło w późniejszym okresie do rozwiązań posiadających wysoki stopień rzeczywistej, a nie iluzorycznej prostoty. Faktem jest także, że w obecnym stanie nauki istnieje wiele teorii, które są wyrazem odejścia od pierwotnych idealizujących uproszczeń, nie widać natomiast ciągle perspektywy włączenia tych teorii $\mathrm{w}$ jedno proste rozwiązanie. $\mathrm{Za}$ przykład może tu służyć naruszenie symetrii w słabych oddziaływaniach. Wszechświat z obowiązującymi bezwzględnie zasadami zachowania byłby bardziej prosty ontycznie niż wszechświat, w którym na mikropoziomie naruszona jest zasada zachowania parzystości.

$\mathrm{Z}$ przykładów tego typu nie wynika jednak, jak to sugeruje M. Bunge ${ }^{22}$, iż kryterium prostoty posiada mitologiczny tylko charakter. Wynika jedynie, iż rozróżnienia między poszczególnymi typami prostoty oraz między prostotą i uproszczeniem dalekie są od jednoznacznego ujęcia w perspektywach współczesnej filozofii nauki. Przy ocenie względnej prostoty badanych ujęć istotną wydaje się być zasada orzekająca, iż metodologicznie dopuszczalne jest porównywanie prostoty formalnej teorii należących do różnych paradygmatów, natomiast usiłowanie porównania prostoty ontycznej czy semantycznej rozwiązań należących do odmiennych paradygmatów może się okazać czynnością bezsensowną. Porównując prostotę ontyczną rzeczywistości ukazywanej w kosmologii filozoficznej Parmenidesa z prostotą ontyczną implikowaną przez teorię Einsteina można dojść do absurdalnych, heurystycznie

22 The Myth of Simplicity. Problems of Scientific Philosophy, Prentice Hall 1963, 71-76. Por. też Weight of Simplicity of Scientific Theories, gdzie Bunge podsumowuje ocenę brzytwy Ockhama w sentencji: „Jak z każdą brzytwą trzeba się z nią obchodzić ostrożnie. W nauce, jak u fryzjera, lepszy żywy brodacz, niż wygolony trup”. „Phil. of Sc.”, 28 (1961) 149. 
nietwórczych wniosków. Konfrontacja tego typu możliwa jest jednak, gdy bierze się pod uwagę walory formalne porównywanych teorii. Można wtedy orzekać, bez wpadania w wewnętrzne sprzeczności, iż na gruncie określonego języka $\mathrm{J}$ teoria Einsteina jest formalnie prostsza od teorii Newtona czy Ptolomeusza.

Podsumowując powyższe wnioski trzeba stwierdzić, iż de iure niemożliwe jest wypracowanie dowodu za onty,czną prostotą przyrody. Nawet znalezienie słynnego ,jednego równania” nie stanowiłoby takiego dowodu, gdyż niemożliwe byłoby wykluczenie przypuszczenia, że dalszy rozwój przyrodoznawstwa przyniesie nowe odkrycia trudne do pogodzenia $\mathrm{z}$ równaniem, podobnie jak przełom $\mathrm{XIX} / \mathrm{XX}$ wieku doprowadził do odkryć niemożliwych do pogodzenia $\mathrm{z}$,prawie doskonałą" fizyką końca ubiegłego stulecia. Zasada prostoty natury ma charakter tak podstawowy, iż niemożliwe jest jej wyprowadzenie dedukcyjne $\mathrm{z}$ innych bardziej podstawowych, ogólniejszych zasad. Można by natomiast podejmować próbę argumentacji za prostotą ontyczną stosując schemat sprowadzania do niedorzeczności negacji dowodzonej te zy.

Przed podjęciem zasygnalizowanej próby należy zwrócić uwagę, iż nie istnieje jedna akceptowana powszechnie definicja prostoty ontycznej. Definicja taka musi więc mieć charakter projektujący, a tym samym pojęcie prostoty ontycznej musi zostać zrelatywizowane do zbioru cech uważanych za konieczne następstwa prostoty. Określając przy pomocy definicji cząstkowych zbiór cech $\mathrm{C}_{1}, \mathrm{C}_{2} \ldots \mathrm{C}_{\mathrm{k}}$, bez których nie można sensownie orzekać o istnieniu ontycznej prostoty świata, możliwe jest stworzenie ciągu niepokrywających się definicji $\mathrm{P}_{1}, \mathrm{P}_{2} \ldots \mathrm{P}_{\mathrm{k}}$. Skutkiem tego wykazanie, iż rzeczywistość jest ontycznie prosta $\mathrm{w}$ sensie $\mathrm{P}_{1}$ nie musi stanowić rozstrzygnięcia problemu prostoty definiowanej jako $P_{2}$ czy $P_{k}$. Sytuacja taka jest mastępstwem braku jednej definicji prostoty świata. Mimo istniejących trudności, możliwe jest wykazanie drogą rozumowania a pagogicznego, iż wszechświat jest ontycznie prọsty w sensie $P_{1}$. Jest to możliwe, jeśli wykaże się, iż negacja tezy o antycznej prostocie przyrody prowadzi do konsekwencji, które po konfrontacji z wynikami doświadczenia trzeba uznać za kontrfaktyczne. Jeśli po wykazaniu kontrfaktycznego charakteru nie wskaże się możliwości odmiennego tłumaczenia danych empirycznych, trzeba uznać za prawdziwą tezę, którą poddan negacji. Rozumowanie takie przebiegałoby zgodnie ze schematem $\{[(p \Rightarrow q) \wedge(\sim p \Rightarrow \sim q)] \wedge q\} \cdot \Rightarrow p$

$\mathrm{W}$ proponowanym ujęciu można wyróżnić trzy etapy rozumowania

1. $\mathrm{p} l \Rightarrow \mathrm{q}$

2. $\sim \mathrm{p} \Rightarrow \sim \mathrm{q}$

3. $\mathrm{Vq}$ 
W etapie pierwszym wprowadza się cząstkową definicję $P_{1}$ prostoty ontycznej p przez odwołanie do zespołu zjawisk q, które są koniecznym następstwem prostoty $\mathrm{p}$ i bez których wystąpienia niemożliwe byłyby wypowiedzi o ontycznej prostocie świata ${ }^{23}$.

W etapie drugim stosując schemat reductio ad absurdum zakłacia się negację tezy o prostocie ontycznej i wykazuje się, iż następstwem tego jest zanegowanie możliwości wystąpienia zjawisk q, uwzględnionych $w$ definiensie definicji $P_{i}$.

W etapie trzecim przez analizę procesów występujących $\mathrm{w}$ realnym świecie wykazuje się kontrfaktyczny charakter wniosku $\sim$ q i uznając faktualność $q$ dochodzi się $w$ ostatecznej konkluzji do uznania tezy Vp - istnieje prostota ontyczna $\mathrm{w}$ sensie $\mathrm{P}_{\mathrm{i}}$. By $\mathrm{w}$ etapie drugim możliwa była asercja, iż bez prostoty ontycznej mie istniałby pewien zespół zjawisk obserwowany przez obserwatora O, konieczne jest przeprowadzenie analizy krytycznej założeń teoriopoznawczych przyjmowanych implicite $\mathrm{w}$ argumentacji.

W koncepcji rozwijanej $\mathrm{w}$ niniejszej pracy jako konieczne następstwa prostoty ontycznej świata przyjmuje się idealizowalność i kierunkowość procesów zachodzących w przyrodzie. Gdyby wszechświat nie był ontycznie prosty, czymś całkowicie niepojętym byłaby możliwość idealizacji i stosowania praw diachronicznych do układów fizycznych. Z drugiej strony gdyby we wszechświecie niemożliwa była idealizacja a w zachodzących procesach nie można by wskazać (określić stosując predykcję czy retrodykcję) kierunku rozwoju, wszechświata takiego nie można by w żadnym sensie określać mianem ontycznie prostego. Bliższej precyzacji wymagają na obecnym etapie rozważań pojęcia idealizowalności i kierunkowości.

\section{POSTULAT PROSTOTY ONTYCZNEJ A TEORIA SYSTEMOW}

Rozwijając argument za ontyczną prostotą przyrody przez uwzględnienie idealizowalności i kierunkowości systemów istniejących w przyrodzie chcę nawiązać do idei sformułowanych przez Ludwiga von Bertalanffy'ego w jego ujęciu teorii systemów. Termin „system” w proponowanym ujęciu będzie denotował systemy rzeczywiste, pozalogiczne, nie zaś systemy pojęciowe, które są także szeroko badane w teorii

${ }_{23}$ Definiowane $w$ ten sposób pojęcie prostoty będzie miało charakter nieostry. Nie jest to jednak zarzut przeciwko wprowadzanej tu definicji, gdyż definicje cząstkowe prowadzą z zasady do pojęć nieostrych. Nieostrość ta jest stopniowalna i uzależniona od tego, czy w okresie warunkowym definicji cząstkowej uwzględnia się tylko warunki wystarczające, czy też warunki konieczne, bądź niektóre warunki konieczne i niektóre warunki wystarczające. Zob. W. Marciszewski, Definicja czqstkowa, w: Mała Encyklopedia Logiki, Wrocław 1970, 35 n. 
systemów. Według Bertalanffy'ego rozpatrywanie w naukowym studium galaktyki, atomu, samochodu, komórki czy zwierzęcia jako systemów ${ }^{24}$ nie ogranicza się do rozwijania powierzchownych analogii 25 , lecz umożliwia sformułowanie wniosków istotnych dla analiz wielu podstawowych, trudnych i nie rozwiązanych dotychczas zagadnien. W wyniku badań empirycznych można stwierdzić, iż wbrew opiniom XIX-wiecznych mechanicystów struktura i funkcjonowanie poszczególnych systemów nie mogą być wyjaśnione przez zwykłe uwzględnienie własności izolowanych elementów składowych danego systemu. System jako całość posiada własności, których wystąpienia nie można przewidzieć na podstawie analizy jego części składowych branych oddzielnie 26. Dlatego też konstruując teorie opisujące systemy skazani jesteśmy, tak jak to określił Popper, na wieczne zgadywanie. W poszczególnych etapach zgadywanie to może być ułatwione przez świadomość prawdy, iż system jako całość odzwierciedla pewien ład, w którego badaniu przydatne są określone racjonalne zasady.

System można charakteryzować przez uwzględnienie relacji zachodzących pomiędzy poszczególnymi elementami składowymi. W opisie wewnętrznej dynamiki systemu złożonego $\mathrm{z} \mathrm{m}$ elementów, wystarczy odwołanie do $n$ zmiennych stanowych, gdzie $n \ll m$, by scharakteryzować stabilność, rozwój, zachowanie finalne czy ekwifinalne ${ }^{27}$ badanego systemu. Charakterystyka ta może być dokonana za pośrednictwem układu n równań różniczkowych typu

$$
\frac{d Q_{n}}{d t}=f\left(Q_{1}, Q_{2} \ldots Q_{n}\right) \text {. }
$$

Dla ontycznej prostoty przyrody istotnymi cechami charakterystycznymi systemów są:

1. nieaddytywność elementów składowych systemów

2. możliwość idealizacji i modelowania ${ }^{28}$ przez pominięcie roli niektórych $(m-n)$ części składowych systemu dla jego funkcjonowania jako całości

3. kierunkowość rozwoju systemu przejawiająca się $\mathrm{w}$ tym, iż zachodzące zmiany nie mają charakteru chaotycznego, lecz z różnych teo-

${ }^{24}$ Zob. Historia rozwoju $i$ status ogólnej teorii systemów, w: Ogólna teoria systemów. Tendencje rozwojowe, Warszawa 1976, 27-47.

25 Tamże, 42, 33.

26 Tamże, $28 \mathrm{n}$. Por. też Problems of Life. An Evaluation of Modern Biological Thought, New York 1952, 200, 148.

${ }^{27}$ Ekwifinalność oznacza dążenie do osiągnięcia określonego stanu końcowego w sposób względnie niezależny od warunków początkowych. Zob. szerzej A. Rapoport, Zastosowanie izomorfizmu matematycznego, w: Ogólna teoria..., $58 \mathrm{n}$.

${ }_{28}$ Przez model (w sensie metodologicznym, a nie semantycznym) rozumiany jest $\mathrm{w}$ tym kontekście zbiór idealizacyjnych założeń. 
retycznie możliwych kombinacji stanów preferowane są pewne ciągi stanów dające się opisać, ująć w prawa, przewidzieć.

Pierwsza z podanych wyżej cech pozwala wytłumaczyć sytuacje, w których rozwój nauki zdaje się prowadzić do ukazania wzrostu stopnia komplikacji struktur przyrody, nie zaś wzrostu prostoty. Sytuacje takie nie stanowią falsyfikatorów tezy o prostocie natury, jeśli przyrodę traktuje się jako zbiór układów nieaddytywnych. Poszczególne elementy składowe systemu mogą nie posiadać własności, które posiada system jako całość. Brak prostoty określonych teorii może być oznaką, iż konieczne jest albo uwzględnienie struktur wyższego poziomu, poniżej którego nie można dostrzec funkcji charakterystycznych dla systemu jako całości, albo - przy pozostaniu na badanym dotychczas poziomie - konieczne jest uwzględnienie roli dodatkowych elementów systemu.

O ile nieaddytywność systemu umożliwia obronę tezy o prostocie natury przez przedwczesną falsyfikację, to podatność na idealizację stanowi podstawę pozytywnych argumentów za tą prostotą. Można by wyobrazić sobie rzeczywistość złożoną z układów, w których niemożliwa byłaby idealizacja. Do opisu jakiegokolwiek zjawiska konieczne byłoby wtedy uwzględnienie wszystkich zależności między wszystkimi oddziaływającymi elementami. Jeśliby nawet założyć liniowy charakter tych oddziaływań, które to założenie byłoby już mocnym wyrazem wiary $\mathrm{w}$ prostotę przyrody, dla układu złożonego $\mathrm{z} \mathrm{n}$ elementów trzeba by było uwzględnić $2^{n}$ oddziaływań. Gdy $n=10^{5}$, co stanowi układ niewspółmiernie mały $\mathrm{w}$ porównaniu $\mathrm{z}$ potrzebami fizyki makrokosmosu (liczba Avogadro - 6,02 $10^{24}$ ) czy biologii organizmu, trzeba byłoby uwzględnić $10^{30103}$ oddziaływań. Prowadziłoby to do układu $10^{30103}$ równań różniczkowych i w praktyce czyniłoby całkowicie niemożliwym uprawianie nauki. Gdyby przyroda była nieidealizowalna, kosmolog, który przyjąłby np. Eddingtonowski model wszechświata zawierającego $10^{79}$ atomów, musiałby charakteryzować procesy ewolucyjne wprowadzając przynajmniej $2^{10^{79}}$ równań różniczkowych. Wszechświat taki, mimo ogromnej złożoności, byłby jednak pod tym względem prostszy od obserwowanego obecnie Wiszechświata. że oddziaływanie dwóch dowolnych elementów nie byłoby w nim zakłócone przez wpływ elementów pozostałych. We wszechświecie tym jedynym teoretycznym modelem wszechświata byłaby jego dokładna kopia. W warunkach takich nie można by orzekać o prostocie gnozeologicznej czy formalnej, nie można by rozwiązywać nietrywialnych problemów dotyczących struktur wszechświata a dopuszczalne byłoby tylko opisywanie rzeczywistości przy pomocy szczegółowych zdań faktograficznych. Sytuacja taka byłaby konsekwencją faktu, iż rozwiązywanie układów złożonych z $10{ }^{30000}$ 
równań różniczkowych przekracza możliwości nie tylko matematyków, lecz także maszyn cyfrowych przyszłości ${ }^{29}$.

Idealizacja stosowana jest $\mathrm{w}$ praktyce nauk przyrodniczych od początku ich rozwoju, stąd też psychologicznie wydaje się ona czymś całkowicie naturalnym. Podstawowe odkrycia przyrodoznawstwa byłyby niemożliwe, gdyby ich autorzy nie stosowali idealizacji. Prawo oddziaływania grawitacyjnego nie zostałoby sformułowane, gdyby Newton nie rozpatrywał wyidealizowanego układu złożonego z dwu obiektów, lecz kierując się realizmem chciał uwzględniać np. wpływ pyłu kosmicznego lub asteroidów. Usprawiedliwienia, iż masa asteroidów jest znikomo mała $\mathrm{w}$ porównaniu $\mathrm{z}$ masą badanych obiektów mie tłumaczą niczego, gdyż masa np. przysadki mózgowej stanowi ok. $10^{-5}$ masy ciała ludzkiego, a przecież niemożliwe jest pominięcie roli tego hormonu w idealizującym opisie zachowań człowieka przedstawianym w perspektywach fizjologii organizmu. Podobnie zawartość DNA w komórce somatycznej u człowieka wynosi ok. $6,5 \cdot 10^{-12} \mathrm{~g}$, a mimo to $\mathrm{w}$ analizach $\mathrm{z}$ zakresu biologii organizmu niedopuszczalne jest pominięcie jego roli. Nie zmienia to faktu, iż $w$ opisach np. zjawisk genetycznych można w wyniku stosowania idealizacji i metod matematycznych uprościć opisywane zjawiska do tego stopnia, że zostaną one zredukowane do przypadków czysto abstrakcyjnych ${ }^{30}$. We współczesnej filozofii nauki podtrzymywane są nawet poglądy, iż w obecnym przyrodoznawstwie najbardziej rozwinięte są te działy, w których maksymalnie stosuje się metody idealizacji. Jako cel rozwoju metod badawczych proponuje się w tym ujęciu przejście od indukcjonistyczno-fenomenalistycznego opisu do esencjalistycznej idealizacji ${ }^{31}$. Ujęcia takie doskonale harmonizują zarówno z tezą o heurystycznych walorach kryterium prostoty, jak i z twierdzeniem, że idealizowalność stanowi warunek konieczny prostoty ontycznej.

W przedstawionych tu analizach idealizacja pojmowana jest jako proces wprowadzania kontrfaktycznych założeń, w których przyjmuje się, że oddziaływanie elementów $\mathrm{E}_{1}, \mathrm{E}_{2} \ldots \mathrm{E}_{\mathrm{n}}$ systemu $\mathrm{S}$ wpływa w stopniu zerowym na własności tego systemu, tzn. iż rola tych elementów

${ }_{29}$ Por. H. J. Bremermann, Complexity and Transcomputability, w: The Encyclopaedia of Ignorance, Oxford 1977, 167-174; W. W. Bledsoe, A Basic Limitation of the Speed of Digital Computers, "IRE Trans. El. Comp. EC - 10" (1961) 530; W. R. Ashby, Systemy $i$ ich miary informacyjne, w: Ogólna teoria systemów..., 82.

${ }_{30}$ Por. P. Grieb, Pojęcie fitness $w$ genetycznych teoriach ewolucyjnych, w: Ewolucja biologiczna. Szkice teoretyczne i metodologiczne, Warszawa 1974, 127.

${ }_{31}$ Por. K. Eastowski, Konstrukcja praw idealizacyjnych $w$ biologii, w: Poznańskie Studia z Filozofii Nauki, t. 1, Teoria a rzeczywistość, Poznań 1976, 66-68.

${ }_{32}$ Por. L. Nowak, Prawda względna - korespondencja - prawda absolutna - praktyka, w: Zasada korespondencji w fizyce a rozwój nauki, Warszawa $1974,152$. 
jest nieistotna dla funkcjonowania $\mathbf{S}^{32}$. Stosowanie tej procedury umożliwia formułowanie twierdzeń idealizacyjnych typu:

$$
\mathrm{F}(\mathrm{S}) \wedge \mathrm{E}_{1}(\mathrm{~S})=\mathrm{O} \wedge \mathrm{E}_{2}(\mathrm{~S})=\mathrm{O} \wedge \ldots \wedge \mathrm{E}_{\mathrm{n}}(\mathrm{S})=\mathrm{O}
$$

gdzie $\mathrm{F}(\mathrm{S})$ denotuje zbiór założeń realistycznych, w których uwzględniona jest rola elementów istotnych systemu S. Oczywiste jest, iz w procesie naukowego studium rzeczywistości formułowanie twierdzeń tego typu nie stanowi ostatecznego celu nauki, lecz tylko środek do określania stanów systemu $\mathrm{S}$ nieuwzględnionych w opisie $\mathrm{F}(\mathrm{S})$. Procedura ta przebiega według schematu:

$$
\left[\mathrm{F}(\mathrm{S}) \wedge\left(\mathrm{E}_{1}(\mathrm{~S})=\mathrm{O} \wedge \mathrm{E}_{2}(\mathrm{~S})=\mathrm{O} \wedge \ldots \wedge \mathrm{E}_{\mathrm{n}}(\mathrm{S})=\mathrm{O}\right)\right] \Rightarrow \mathrm{G}(\mathrm{S})
$$

Podobny schemat logiczny może być stosowany w stadium przyrodniczym $\mathrm{z}$ tej racji, że poszczególnym systemom przysługuje nie tylko idealizowalność, lecz także kierunkowość czy antyprzypadkowość, przejawiająca się $\mathrm{w}$ tym, że $\mathrm{w}$ ewolucji systemu opisywanego przez uwzględnienie zbioru $n$ istotnych elementów $\left(\mathrm{E}_{1}, \mathrm{E}_{2} \ldots \mathrm{E}_{\mathrm{k}}\right)$ nie wsizystkie kombinacje elementów zbioru są jednakowo prawdopodobne, lecz istnieje klasa wyróżnionych kombinacji charakteryzujących kierunek rozwoju S. Można by wyobrazić sobie system, w którym dopuszczalna byłaby idealizacja, a mimo to oddziaływania elementów istotnych miałyby charakter chaotyczny, nieskoordynowany,- nie dający się ująć w prawa, uniemożliwiający predykcję czy retrodykcję. W rzeczywistości takiej ze względu na jednakowe prawdopodobieństwo wystąpienia dowolnej kombinacji elementów zbioru $\mathrm{S}$ nie można by stosować schematu $\mathrm{F}(\mathrm{S}) \Rightarrow \mathrm{G}(\mathrm{S})$.

Tak pojmowanej kierunkowości procesów nie należy utożsamiać z kierunkowym upływem czasu. Uwzględniając rozróżnienie między lokalną strzałką czasu a jego globalnym kierunkiem ${ }^{33}$ należy zauważyć, że już istnienie lokalnej strzałki daje podstawy do orzekania o kierunkowości procesów. Nieistotne jest także, który z uwzględnianych procesów jest antecedensem a który jego następstwem; podstawowy jest sam fakt niechaotycznego rozwoju systemów istniejących $\mathrm{w}$ przyrodzie. Następstwem kierunkowości przyrody jest jej tzw. matematyczność. W praktyce badawczej przyzwyczajono się do faktu, iż przyroda jest matematyczna i jej zachowanie można opisywać przy użyciu zasad logiki. Z filozofícznego punktu widzenia jest to jednak element zaskakujący, przy którym trudno uniknąć pytania o rację dostateczną. Przyroda mogłaby być skomplikowana i ewoluować w sposób wyrafinowany

ss Bliższe precyzacje zob. M. Heller, The Origins of Time, w: The Study of Time, t. 4, (w druku). 
nie pozwalając na określenie żadnych praw rozwoju i czyniąc niemożliwym studium naukowe. M. in. A. Einstein podkreślał często, iż czymś całkowicie niepojęte jest to, że wszechświat stanowi układ ewoluujący według ściśle określonych praw, nie zaś absolutny chaos ${ }^{34}$. W niechaotycznym wszechświecie procesy ewolucji przebiegają zgodnie z prostymi formułami Einsteinowskich równań pola, matomiast w systemie biologicznym, jakim jest ludzki organizm, można np. wzrost stężenia cukru we krwi po wstrzyknięciu glukozy opisać za pomocą prostej funkcji wykładniczej $\mathrm{C}_{\mathrm{t}}=\mathrm{C}_{\mathrm{o}} \mathrm{e}^{-\mathrm{kt}}$.

Kierunkowość zmian jest zagadnieniem, którego interpretacja kauzalna przekracza kompetencje nauk przyrodniczych. Filozofujący przyrodnicy podejmując to zagadnienie uciekają się niejednokrotnie do panteizujących uwag, albo - jak w przypadku Teilharda de Chardin, J. Huxleya czy T. Dobzhansky'ego ${ }^{35}$ - do ponadnaturalistycznych tłumaczeń. W ujęciach najostrożniejszych metodologicznie analiza kierunkowości procesów ogranicza się do postawienia pytania o uwarunkowanie obserwowanego porządku struktur czy harmonii funkcjonalnej. L. van Bertalanffy pisze na ten temat: „«siły organizmu» i «prawa organizacji» są widoczne na różnych poziomach od spirali białka i kwasów nukleinowych do włókien i organellów typu mitochondriów, które mają możność rekonstytucji po poważnych uszkodzeniach... Natura tych sił organizujących nie jest obecnie wystarczająco znana, lecz ich następstwa mogą być wykazane obserwacyjnie... W interpretacjach nie przyjmuje się orzekań, iż w dostatecznie długim okresie czasu przypadkowe zdarzenia doprowadzą do powstania każdej możliwej w zasadzie konfiguracji chemicznej. Struktura chemiczna pary pończoch nylonowych jest dużo prostsza od struktury chemicznej łańcuchów kwasów nukleinowych, a jednak nie oczekujemy znalezienia nylonów powstałych w wyniku «spontanicznego zrodzenia» czy «przypadkowej reakcji»" 36 .

Ow antyprzypadkowy charakter przyrody, dostrzegany najłatwiej w procesach przyrody ożywionej lecz stanowiący również konieczny warunek istnienia kosmologii jako mauki, jest istotnym wskaźnikiem prostoty systemów fizycznych. Gdyby każde zdarzenie w przyrodzie miało charakter przypadku, nie można by przyrody jako takiej nazywać prostą. Wskazując idealizowalność i kierunkowość jako podstawowe oznaki prostoty ontycznej przyrody nie zamierzam, oczywiście, kontynuo-

${ }^{34}$ Por. np. A. Einstein. A Documentary Biography, ed. by C. Seelig, London 1956: „I can, if the worst comes to the worst, still realise that the good Lord may have created a world in which there are no natural laws. In short chaos".

${ }_{35}$ Zob. szerzej np. L. von Bertalanffy, Perspectives on General System Theory. Scientific - Philosophical Studies, New York 1975, 143.

36 Tamże, $14 \mathrm{n}$. 
wać analiz w stylu Leibniza czy Parmenidesa i wykazywać, że wszechświat jest najprostsszy z możliwych. Przesłanką, którą by można zakwestionować we wprowadzanym rozumowaniu, jest implikacja $\sim p \Rightarrow \sim$ c: gdyby wszechświat nie był ontycznie prosty, niemożliwa byłaby idealizacja i nie można by określić kierunku przebiegu procesów. Przesłankę tę można by kwestionować argumentując, że idealizowalność i kierunkowość nie istnieją obiektywnie w systemach fizycznych, lecz są rezultatem działalności intelektualnej podmiotu poznającego.

Wskazany zarzut dotyczy założeń noetycznych i epistemologicznych. Widoczne są w nim inspiracje Kantowskiego rozróżnienia między podmiotowymi kategoriami a rzeczą samą w sobie. Dlatego też należy przebadać obecnie propozycje teoriopoznawcze opozycyjne w stosunku do zakładanego w niniejszej pracy realizmu krytycznego, po to, aby udzielić odpowiedzi na pytanie, w jakim stopniu spójne i uzasadnione są te interpretacje, w których oznaki uznane za wskaźniki prostoty ontycznej uważane byłyby jedynie za rezultaty ludzkiej aktywności poznawczej, a nie cechy przysługujące obiektywnie rzeczywistości.

\section{PROBLEM PROSTOTY A ZAEOŻENIA TEORIOPOZNAWCZE}

Przedstawioną argumentację za ontyczną prostotą przyrody można by zakwestionować odrzucając tezy realizmu krytycznego i argumentując, iż matematyczność i harmonijność przyrody są jedynie wynikiem tego, iż zarówno zasady logiki, jak i całe ludzkie poznanie jest rezultatem procesu ewolucji. Ewoluująca przyroda doprowadziła do ukształtowania takiego mózgu człowieka, iż przy pomocy określonych praw logiki może on ujmować rzeczywistość jako prostą. Gdyby nie istniały te uwarunkowania ewolucyjne, przyroda w swych najgłębszych strukturach byłaby dla człowieka niepoznawalną.

Tego typu ewolucjonistyczna interpretacja prostoty przyrody wydaje się natrafiać na większe trudności niż rozwiązania opozycyjne w stosunku do miej. Nie istnieją pozytywne argumenty za tym, by traktować odczucie harmonijności świata jako naturalny produkt ewolucji filogenetycznej. W procesie ewolucji można ustalić odpowiedniość między powstającymi w wyniku filogenezy nowymi cechami określonego gatunku a konkretnymi warunkami, do których zachodzi konieczność przystosowania. Swiadomość matematyczności przyrody czy estetyczną fascynację jej względną prostotą trudno jest zaliczyć do podobnych cech umożliwiających spełnianie koniecznych zadań w danym stadium rozwoju. $\mathrm{Na}$ niekorzyść interpretacji ewolucjonistycznej żdaje się także przemawiać sam fakt, iż dopiero w wieku XVII powstał rachunek różniczkowy umożliwiający w sposób wyrazisty wykazanie, matematyczne- 
go charakteru procesów fizycznych. Pierwotnego człowieka nie fascynowała przyroda swym matematycznym pięknem, lecz przerażała lub zaskakiwała niepojętym nieznanym. Bariera tysięcy, jeśli nie milionów, lat oddzielających początki logicznego myślenia u gatunku homo sapiens od początków rachunku ukazującego wyraziście matematyczny charakter przyrody upoważnia do kwestionowania prób tłumaczenia obu tych mastępstw przez odwołanie się do procesów ewolucyjnych.

Analiza procesu powstawania mowych teorii fizykalnych zdaje się umacniać przedstawiane wątpliwości. Jeśli bowiem dążenie do prostoty gnozeologicznej jest istotną cechą umysłu ludzkiego wytworzomą przez ewolucję, to trudno jest wyjaśnić, dlaczego w pewnych okresach ów naturalny pęd zawodził. W pewnych stadiach rozwoju nauki nie dostrzegano wszak relatywnie prostych rozwiązań, usiłowano bronić teorii bardziej skomplikowanych albo też uważano zagadnienie za niemożliwe do rozwiązania. Zważywszy, iż sytuacje takie nie należą do wyjątkowych $\mathrm{w}$ procesie rozwoju nauki, trzeba byłoby $\mathrm{w}$ celu obrony interpretacji ewolucjonistycznej wyjaśnić, dlaczego wytworzony w człowieku ,zmysł prostoty" funkcjonuje w obrębie określonych paradygmatów naukowych, natomiast zawodzi w sytuacjach przed rewolucją naukową, przy przesunięciu paradygmatu.

Do podobnych wniosków prowadzi analiza trudności $\mathrm{z}$ interpretacją mechaniki kwantowej. Trudności te doprowadzily do opinii o zasadniczo odmiennym charakterze zjawisk mikrokosmosu, o potrzebie wypracowania odrębnej logiki kwantowej, o nieprzydatności w mikrokosmosie schematów pojęciowych obowiązujących na poziomie makrokosmosu ${ }^{37}$. Uwzględniając fakt, iż w procesie ewolucji istotny wpływ miały zjawiska dokonujące się na poziomie mikrokosmosu (DNA, nukleopeptydy), trzeba by znowu wyjaśnić, dlaczego uksiztałtowały one tạ ludzkie poznanie i zasady logiki, 'iż rzeczywistość makrokosmosu jawi się człowiekowi jako prosta, harmonijna i matematyczna, zaś mikroświat jako skomplikowany, naruszający schematy pojęciowe i wymagający odrębnej logiki.

Analogiczna sytuacja powstaje przy badaniu pewnych zjawisk na poziomie makrodoświadczenia. Pewne procesy i struktury również na tym poziomie jawią się jako chaotyczne i skomplikowane. Przyjęcie tezy o ewolucyjnym uwarunkowaniu odczucia prostoty czyniłoby znowu trudnym do wyjaśnienia fakt, iż $w$ procesach tych zawodzą ewolucyjnie warunkowane odczucia i rzeczywistość jawi się jako chaotyczna $\mathrm{i}$ nieuporządlkowana. Można by wprawdzie wprowadzić ad hoc do-

37 Zob. np. C. A. Hooker, Metaphysics and Modern Physics, w: Contemporary Research in the Foundations and Philosophy of Quantum Mechanics, Dordrecht 1973, 174-305; por. też R. J. Greechie, Quantum Logics, tamże, 143-173. 3 - Analecta Cracoviensia 
datkowe założenie, iż istnieje górna granica złożoności układu, powyżej której nawet wytworzone przez ewolucję odczucie prostoty zawodzi i nie jest $\mathrm{w}$ stanie przedstawić rzeczywistości jako prostej. Podobne kompromisowe tłumaczenie oznaczałoby jednak $\mathrm{w}$ praktyce uznanie zróżnicowania złożoności ontologicznej struktur pr zyrody i byłoby bardzo bliskie stanowisku zajętemu w poprzednim paragrafie niniejszego artykułu.

Pomijając tezę o ewolucyjnym uwarunkowaniu prostoty można by kwestionować ontyczną prostotę świata na gruncie epistemologii opozycyjnej w stosunku do realizmu krytycznego. W podejmowanych obecnie próbach kwestionowania tradycyjnej epistemologii proces poznawania interpretowany jest nie jako odtworzenie czy odbicie struktur istniejących niezależnie od umysłu, lecz jako proces, którego ostateczny wynik uzależniony jest w dużym stopniu od strukturalizacji układu nerwowego i subiektywnych uwarunkowań podmiotu poznającego ${ }^{38}$. Tego typu interpretacje, w których proces poznania charakteryzowany jest przez odwołanie do selekcji informacyjnej, przekształceń, kodowań, szumów etc., nie dają się pogodzić ze stanowiskiem realizmu naiwnego. W artykule niniejszym stanowisko to nie jest jednak przyjmowane. Pozostaje więc otwartą kwestia, czy informatyczne ujęcie epistemologii musi prowadzić do zakwestionowania wniosku o ontycznej prostocie świata. Byłoby to uzasadnione, gdyby odwzorowanie zbioru danych empirycznych $\mathrm{E}$ na zbiór korelatów poznawczych $\mathrm{P}$ stanowiło przypadek swoistego odwzorowania epimorficznego @. Swoistość tego epimorfizmu przejawiałaby się $\mathrm{w}$ tym, iż $\mathrm{P}$ byłby obustronnie ograniczony posiadając kres górny sup $P$ i kres dolny inf $P$. W następstwie ograniczoności $P$ i nieograniczoności $\mathrm{E}$ relacja $\mathrm{p} \in \mathrm{P} \mathrm{R}$ e $\in \mathrm{E}$ byłaby relacją jedno - wieloznaczna i dla każdego elementu e $\in \mathrm{E}$ spełniony byłby warunek inf $\mathrm{P}<\varrho(\mathrm{e})<$ sup $P$.

Przyjmując podobny model procesów poznawczych można by stosunkowo łatwo uzasadnić gnozeologiczną prostotę poznania ludzkiego czy matematyczność przyrody. Zbiór właściwych człowiekowi korelatów poznawczych posiadałby $\mathrm{w}$-tym ujęciu taką strukturę, iż niezależnie od stopnia komplikacji danych empirycznych odwzorowanie tych danych na $\mathrm{P}$ nie mogłoby przekroczyć pewnego stopnia komplikacji określonego przez sup $P$.

Przy ocenie interpretacji równoważnych ze wskazaną trzeba rozróżnić między podstawowymi ideami a konkretnymi rozwiązaniami. Idea systemowej interpretacji epistemologii jest obecnie stosunkowo popularna. Nie implikuje ona jednak tezy o e pimorfizmie procesu po-

\footnotetext{
${ }^{38}$ Zob. W. Buckley, Epistemologia w ujęciu systemowym, w: Ogólna teoria..., 192; tenże, Sociology and Modern Systems Theory, Prentice Hall 1968.
} 
znạnia. Przeciwnie, można zauważyć dominację ujęć, w których mówi się o izomorfizmie między poznawanymi obiektami i odpowiadającymi im opracowaniami intelektualnymi ${ }^{39}$. Przyjęcie izomorfizmu relacyjnego proponowane przez W. Buckleya pozwala podtrzymywać poglądy realizmu krytycznego $w$ teorii poznania oraz przedstawioną tu argumentację za ontologiczną prostotą przyrody. Opozycyjna koncepcja, w której poznanie ma charakter epimorficzny i zróżnicowanym strukturom rzeczywistości odpowiadają te same schematy pojęciowe, wydaje się być trudna do pogodzenia $\mathrm{z}$ faktem wspólistnienia idealizacji i falsyfikacji w perspektywach nauk przyrodniczych. Skoro bowiem na zbiorze $\mathrm{E}$ danych empirycżnych można przeprowadzić określone zabiegi idealizacyjne $\varphi_{1}, \varphi_{2} \ldots \varphi_{\mathrm{n}}$ i wyniki tego typu przekształceń opisują rzeczywistość w sposób zadowalający, mimo kontrfaktycznego charakteru założeń, należałoby przeto oczekiwać, iż dowolny zbiór danych empirycznych skutkiem odpowiednich przekształceń będzie mieścił się w granicach określonych struktur pojęciowych, dając spójną teorię rzeczywistości. Tyḿczasem okazuje się, że istnieją podzbiory danych empirycznych $\mathrm{F}_{1}, \mathrm{~F}_{2} \ldots \mathrm{F}_{\mathrm{n}} \subset \mathrm{E}$, które pełnią funkcje falsyfikatorów pewnych teorii, tzn. żadne odwzorowania nie mogą ich przekształcić tak, by obraz $\varrho\left(F_{1} \ldots F_{n}\right) \subset[\inf P$, sup $P]$. W tej sytuacji zbiór $P$ trzeba powiększyć o podzbiór $\varrho\left(\mathrm{F}_{1} \ldots \mathrm{F}_{\mathrm{n}}\right)$.

O ile w proponowanym ujęciu można by sam fakt idealizacji uważać za potwierdzenie tezy o podmiotowych uwarunkowaniach prostoty gnozeologicznej, to fakt wspólistnienia idealizacji i falsyfikacji każe wątpić w zasadność podobnych tłumaczen. Trudną do wyjaśnienia pozostawałaby bowiem kwestia, dlaczego mechanizmy odwzorowania epimorficznego, których można by się dopatrywać w procesie idealizacji, zaczynałyby zawodzić $w$ innych procesach poznawczych dopuszczając falsyfikację prowadzącą do określenia odmiennego obrazu $\varrho(\mathrm{E})$, niż ten, na którym usiłowano określać epimorfizm.

Przedstawiona argumentacja nie może doprowadzić do jednoznacznego i definitywnego rozwiązania problemu, gdyż zarówno hipotezy o ewolucyjnym uwarunkowaniu prostoty, jak i informatyczne analogie z epimorfizmem poznawczym mogą być bronione dowolnie długo przez wprowadzenie arbitralnych założeń ad hoc. Wystarczy np. założyć, iż w rozwoju ewolucyjnym człowieka jako gatunku ulega przemianom także odczucie estetyki i prostoty, co prowadzi w konsekwencji do powiększenia zbioru P o nowe elementy, które we wcześniejszym paradygmacie uważano za elementy dopełnienia P. Interpretacja taka nie jest jednak podatna ani na weryfikację, ani na falsyfikację, co czyni ją interpretacją metafizyczną w Popperowskim sensie tego terminu. Zasad-

${ }^{39}$ Por. Buckley, Epistemologia..., 193. 
niczym wnioskiem przedlstawionych analiz jest natomiast teza, iż ani opinie o podmiotowym (częściowym) uwarunkowaniu prostoty gnozeologicznej, ani próby rozwijania epistemologii na gruncie teorii systemów nie implikują negacji twierdzenia o ontycznej prostocie przyrody. Uznając ostatni wniosek trzeba uznać zasadność implikacji $\sim \mathrm{p} \Rightarrow \sim \mathrm{q}$ : jeśli wszechświat nie jest ontycznie prosty, to niemożliwa jest w nim idealizacja i nie można określić kierunkowości procesów. Ponieważ następnik tej implikacji jest falsyfikowany przez dane obserwacyjne, konsekwentnie po zastosowaniu schematu reductio ad absurdum trzeba uznać za uzasadniony wniosek, iż wszechświat jest ontycznie prosty $\mathrm{W}$ określonym uprzednio sensie $P_{i}$. Wniosek ten pozostawia otwartą kwestię możliwości dyskusji o innych typach ontycznej prostoty przyrody.

\section{AN ATTEMPT AT DEMONSTRATION OF ONTIC SIMPLICITY OF NATURE}

\section{S u m m a r y}

The problem of criterion of simplicity is one of the most complex problems in contemporary philosophy of science. Nearly thirty various types of simplicity are defined in methodological analyses, and increase of simplicity in a given sense yields often simultaneous decrease of simplicity in a different sense. Among these various types of simplicity the most important roles are played by gnoseological and ontic simplicity. The former concerns heuristic values of results of human knowledge expressed e.g. in scientific theories; the latter deals with the objective simplicity of physical structures existing independently of human observer.

Gnoseological simplicity must not imply ontic simplicity, because economy of thinking can be a sufficient reason to accept gnoseological simplicity as a symptom of high heuristic values of appraised theories. Nonetheless, many authors accepting Occam's razor in methodology accept also the scholastic adage „Natura simplicitatem amat".

Two essential properties of physical systems are taken into consideration in the paper in order to prove the thesis about ontic simplicity of Nature. One of them reveals in possibility of idealisation in description of physical systems. The idealisability of Nature permits to interprete properties of physical systems as results of chosen few components and to assume that contributions of other components are equal to zero. This assumption has obviously unrealistic character, but without it science practically could not exist. If the universe were not idealisable, in order to describe e.g. the Eddington's universe containing $10^{79}$ elements one ought to solve $2^{10^{79}}$ differential equations.

The second important symptom of ontic simplicity is an anticasual character of physical systems. This property is revealed in the fact that among various theoretically possible states of a system exists a speciall class of events deciding of direction of diachronic evolution of the system. If this class did not exist, all imaginable situations could be possible, and the evolution of the systems 
could have purely accidental, chaotic, undetermined character. Due to this anti-accidentality, laws of Nature can be defined as well as prediction and retrodiction can be used in description of physical systems.

These two properties are used in the paper to introduce partial definition - $\mathrm{P}_{1}$ - of ontic simplicity of Nature. On account of impossibility to prove positively that Nature is simple in an absolute sense, an apagogic argument is formulated by the author to demonstrate that physical systems are ontically simple in the sense $P_{1}$. The argumentation presented here lefts open the problem of ontic simplicity conceived in a different, not $\mathrm{P}_{1}$, sense. 